\title{
Örgütsel Seçimlerde Küme Modeli : İnsan İlişkileri, Bilgi Yönetimi ve Örgütsel Öğrenmenin Ara Kesitinde "İnsan"
}

\author{
Set Model by Organizational Choice: Human Relations, Knowledge \\ Management and Human Element at the Intersection of Organizational \\ Learning
}

Mustafa Sağsan*

\begin{abstract}
Öz
Bu çalışma, insan ilişkileri, bilgi yönetimi ve örgütsel öğrenme üçgeninde insanın önemini vurgulamayı amaçlamaktadır. Bu bağlamda, insan ilişkileri yaklaşımı, örgütsel bilgi yönetimi alanı ve örgütsel öğrenme süreçlerinde insana ilişkin yapısal modeller açıklanmıştır. Çalışmada, bu üç alanın ara kesiti olarak belli insan özelliklerinin önerildiği bir küme modeli geliştirilmiştir. Örgütlerde verimliliğin artması için bu model baz alınarak insana yatırım yapılması gerektiği sonucuna varılmıştır.
\end{abstract}

Anahtar sözcükler: Insan ilişkileri, Bilgi yönetimi, Örgütsel öğrenme, Örgütlerde insan varsayımı, Küme modeli.

\begin{abstract}
This study attempts to combine the concepts of human relations, knowledge management and organizational learning. Also, it emphasizes the importance of information management in human relations approach and the process of organizational learning in human relations. A "set model" of these concepts was developed. Consequent results of this model indicaed the necessify for investment in human capital.
\end{abstract}

Keywords: Human relations, Knowledge management, Organizational learning, Assumption of human in organization, Set model.

\section{Giriş}

Insan ilişkileri ekolü, örgüt teorileri içerisinde insanı sosyal bir varlık olarak görmesi ve çalışanların üretkenliğinin arttırılması yoluyla iş tatminlerinin sağlanması açısından ayrı bir önem taşımaktadır. Bu teori, örgütsel verimliliğin gerçekleşmesinde kilit bir unsur olan insanın ön plana çıkarılması ve birçok alanın yönetim sürecinde yerini alabilmesi açısından büyük önem arz etmektedir. Bu alanlardan bir tanesi de bilgi yönetimidir.

\footnotetext{
“ Öğretim görevlisi, Başkent Üniversitesi Bilgi ve Belge Yönetimi Bölümü (msagsan@baskent.edu.tr).
} 
Örgütlerde bilgi yönetiminin temel dayanağı, bilginin yaratılması ve kullanıcıya/müşteriye erişilme sürecindeki bilgi akışıdır. Bu bilgi akışının gerçekleşmesi ise, ancak örgüt üyelerinin birbirleriyle iyi ilişkiler kurması ile mümkündür. Ayrıca, örgüt içi iletişimin insan odaklı bir biçimde yönlendirilmesi; bilgi yönetiminin gelişmesine ve dolayısıyla örgütün verimliliğinin artmasına neden olmaktadır. 'Örgütsel bilgi yönetim süreci' olarak da nitelendirilebilen bu yaklaşımın devamlılığı ve örgüt için etki derecesinin arttırılması, örgütsel öğrenme ile sağlanabilir. İşte, bu üç alanın örgütsel seçimlerde oluşturduğu ortak ve temel odak noktası "insan"dır. Yani, gerek insan ilişkileri akımının, gerek bilgi yönetimi disiplininin ve gerekse örgütsel öğrenme alanının ortak paydasını oluşturan insanın varlığına özgü varsayımlarının ne olduğuna ilişkin bilgiler, bu çalışma kapsamına alınmıştır. Bu varsayımlardan yola çıkarak geliştirilen kesişim kümesi modeli ile, bu üç alanın ara kesitindeki ortak noktaya ilişkin önermelerde bulunulmuştur. $\mathrm{Bu}$ önermelerden de, örgütsel bilgi yönetiminin verimli olabilmesi için örgütlerin nasıl bir yaklaşımı benimsemesi gerektiği konusunda sonuca varılmıştır.

\section{İnsan İlişkileri Yaklaşımı}

Bilgi ve iletişim teknolojilerinin hızlı bir şekilde gelişmesine paralel olarak, örgüt içerisindeki insanlar arası iletişim giderek önemini yitirmiş ve örgütsel insan ilişkileri yok olma tehlikesi ile karşı karşıya kalmıştır. Bu durum ise, örgütsel bilginin yönetimini olumsuz yönde etkilemiştir.

Örgüt kısaca “...bir grubun belli amaçları gerçekleştirmek için bir araya gelerek oluşturduğu çevreyle etkileşimli, sistemli faaliyetler bütünü” (Hicks, 1979, s.32) şeklinde tanımlanabilir. Örgütler, faaliyet yaptıkları alanlara göre 
çeşitlere ayrılmaktadır. 21. yüzyılda en önemli örgüt türü olarak karşımıza bilgiye dayalı örgütler çıkmaktadır. Bilgi tabanlı örgütlerin en önemli özelliklerinden biri ise insan ilişkilerini geliştirmeye hizmet etmek zorunda olmalarıdır. Çünkü bilgi odaklı örgütlerdeki bu yapının desteklenmesi zorunluluğu, bilgi yönetiminin bir parçasını oluşturmaktadır. O nedenle örgütlerde giderek resmileşen insan ilişkileri yaklaşımı, örgütsel bilgi yönetimi sayesinde yeniden can bulmuştur. Bu yaşamsal döngünün devamlılığı da örgütlerin öğrenme süreci içerisine girmelerine bağlıdır.

Bu ekolün hangi tarihsel süreç içerisinde yer aldığını ortaya koymak için örgüt yönetimi ile ilgili teorik modelleri kategorize ettiği ve bunların temsilcilerini açıkladığı tabakalaştırılmış gösterimi aşağıdaki tabloda verilmiştir. Ayrıca bu model, genel olarak ele alınan insan ilişkilerinin makro düzeydeki örgüt kuramları içerisindeki konumunu anlama amacına yönelik olarak da bir anlam ifade eder.

\begin{tabular}{|c|c|c|c|c|}
\hline \multicolumn{3}{|c|}{ Kapalı Sistem Modeller } & \multicolumn{2}{|c|}{ Açık Sistem Modeller } \\
\hline Analiz Düzeyi & $\begin{array}{c}1900-1930 \\
\text { Rasyonel } \\
\text { Modeller }\end{array}$ & $\begin{array}{c}\text { 1930-1960 } \\
\text { Doğal } \\
\text { Modeller }\end{array}$ & $\begin{array}{c}1960-1970 \\
\text { Rasyonel } \\
\text { Modeller }\end{array}$ & $\begin{array}{l}\text { 1970'den-Bugüne } \\
\text { Doğal Modeller }\end{array}$ \\
\hline $\begin{array}{c}\text { SOSYO } \\
\text { PSÍKOLOJiK }\end{array}$ & $\begin{array}{l}\text { Bilimsel } \\
\text { Yönetim } \\
\text { Taylor (1911) } \\
\text { Karar Alma } \\
\text { Simon (1945) }\end{array}$ & $\begin{array}{c}\text { İnsan } \\
\text { İlişkileri } \\
\text { Whyte (1959) }\end{array}$ & $\begin{array}{c}\text { Sınırlı } \\
\text { Rasyonalite } \\
\text { March \& Simons } \\
(1958)\end{array}$ & $\begin{array}{l}\text { Örgütlenme } \\
\text { Weick (1969) }\end{array}$ \\
\hline \multirow[b]{2}{*}{ YAPISAL } & $\begin{array}{l}\text { Bürokratik } \\
\text { Teori Weber } \\
\text { (1968'lere } \\
\text { geçiş) }\end{array}$ & $\begin{array}{c}\text { İşbirliği } \\
\text { Sistemleri } \\
\text { Barnard } \\
(1938)\end{array}$ & $\begin{array}{l}\text { Koşulbağımlılık } \\
\text { Teorisi } \\
\text { Lawrence \& Lorch } \\
\text { (1967) }\end{array}$ & $\begin{array}{c}\text { Sosyo-teknik } \\
\text { Sistemler } \\
\text { Miller \& Rica } \\
(1967)\end{array}$ \\
\hline & $\begin{array}{c}\text { Yönetsel } \\
\text { Teori } \\
\text { Fayol (1919) }\end{array}$ & $\begin{array}{c}\text { İnsan } \\
\text { İlişkileri } \\
\text { Mayo (1945) }\end{array}$ & $\begin{array}{c}\text { Karşılaştırmalı } \\
\text { Yapı } \\
\text { Woodward (1965) } \\
\text { Pugh vb. (1969) } \\
\text { Blau (1970) }\end{array}$ & - \\
\hline EKOLOJIK & - & $\begin{array}{l}\text { Çatışma } \\
\text { Modelleri }\end{array}$ & $\begin{array}{l}\text { Mübadele } \\
\text { Maliyeti }\end{array}$ & $\begin{array}{l}\text { Popülasyon } \\
\text { Ekolojisi }\end{array}$ \\
\hline
\end{tabular}




\begin{tabular}{|l|c|c|c|}
\hline & $\begin{array}{c}\text { Gouldner } \\
(1954)\end{array}$ & Williamson (1975) & Hannan \& \\
& & & Freeman (1977) \\
Kaynak \\
Bağımlığı \\
& & & Selznick (1949) \\
& & & \\
& & & \\
& & & Turumsallaşma \\
& & Teorisi \\
& & & PiMaggio \& \\
& & & \\
& & &
\end{tabular}

Tablo-1. Egemen Kuramsal Modelleri ve Temsilcileri

Kaynak: Scott, W.R., Organization: Rational, natural and open systems. New Jersey: Prentice Hall.

Tablo 1'de görüldüğü üzere Scott, makro düzeydeki örgüt yapılanmasının ve bakış açısının yıllara göre dağılımını vermektedir. Scott, bu bakış açısıyla söz konusu modelleri iki kategoriye ayırmaktadır. Birinci kategori, 1960’lı yıllara kadar gelen kapalı sistem örgüt yapıları, ikinci kategori ise 1960'dan günümüze kadar gelen açık örgüt yapılarıdır. Her ne kadar kapalı sistem modellerde insan ilişkileri ekolü gibi doğal modeller olsa da, Scott'a göre kapalı yapı modelinden açık yapı modeline geçmek, örgütlerdeki rasyonel modelden doğal modele geçmekle aynı anlamı ifade etmektedir. 1930'ların sonu ile 1940'ların başında Weber ve Taylor makro düzeydeki örgüt yapıları için rasyonel modeller önerirken; 1970’lerde Mayo ve Bernard ise örgütlere doğal bir bakış açısı ile yaklaşmaktadırlar. Scott, 1970'lerin sonlarında bu yapılanmaya yeni rasyonelci yaklaşımları eklemiştir. Aynı tarihlerde Hannan, Meyer ve Pfeiffer örgütler için yeni doğal modeli önermektedirler. 1960’ların sonrasında ise örgütsel çevre, ekonomik, politik, kültürel, sosyal, teknolojik ve birbirleriyle bağlantılı konularda örgüt yapısı ve davranışlarını açıklamaya çalışmışlardır. Tabloda konumuz içerisine dahil olan makro düzeydeki örgüt teorisine gelince bu, 1930-1960’lı yıllarda doğal bir örgüt modeli olarak kapalı sistemler içerisinde yer almaktadır. 


\section{İnsan İlişkileri Ekolünde “İnsan” Faktörü}

Klasik yönetim düşüncesinin genellikle "bilimsel yönetime" dayandırılması, 1930'larda, makro örgüt teorilerinde neo-klasik yönetim anlayışının doğmasına neden olmuştur. İşletmelerin giderek büyümesi ve karmaşıklaşması sonucunda klasik yönetim yaklaşımları, işletmelerin intiyacını karşılamaktan yoksun kalmış ve yönetime yeni ilkeler koymaktan ziyade, klasik yönetimin boşluk ve eksikliklerini tamamlayıcı yönde bir takım çalışmalar geliştirmişlerdir. Klasik yönetimde insanın duygu ve düşüncelerine göre hareket etme isteğinin göz ardı edilmesi, neo-klasik yönetim anlayışını ön plana çıkarmış ve böylelikle insanörgüt ilişkileri bağlamında gerçekleşen davranışlara vurgu yapmıştır. Neo-klasik yönetim düşünce sistemi içerisinde en önemli yaklaşım ise "insan ilişkileri" olmuştur. Bu akımın öncülerinden olan Elton Mayo, işçilere daha fazla anlayış gösterildiği taktirde, endüstriyel işletmelerin daha çok verim sağlayacağı iddiası üzerinde durmuştur (O'Connor, 1999). Bu bağlamda, çalışmanın ilerleyen kısımlarında Elton Mayo'nun Hawthorne Araştırmaları sonucunda ortaya koyduğu insan modelinden bahsedilecektir.

$\mathrm{Bu}$ bölüm, insan ilişkileri yaklaşımının temel argümanlarını ortaya koymaktadır. Ayrıca, insan-örgüt ilişkisi perspektifinden insanın konumlandırılığı temel dayanak saptanmaya çalışılmaktadır.

Insan ilişkileri akımı, Richard Daft'a göre (2000) "yönetim düşüncesi ve uygulamasında, çalışanların üretkenliğini ve işçilerin iş tatminini yükseltme amacına yönelik olarak gerçekleştirilen hareketler" şeklinde tanımlanmaktadır. Bir bakıma bu yaklaşım, hem örgüt yöneticilerinin hem de çalışanların tatminini 
sağlamaktadır. Çünkü, çalışanların örgütsel tatmininin sağlanması; üretkenliği dolayısıyla örgütsel verimliliği arttırmaktadır.

İş ortamındaki yönetim yaklaşımları/seçenekleri ile insan ilişkileri, genel olarak iki bakış açısı altında sonuçlanmıştır. Birincisi endüstriyel ilişkiler veya insan ilişkileridir ki, bu yaklaşım, çalışanla yönetimin arasındaki mesafeyi kaldırarak onların ortak bir noktada buluşmalarını sağlamıştır. İkincisi ise, herhangi bir işyeri çevresindeki insan ilişkilerinin birdenbire oluşmaya başladığı, geliştiği ve büyüdüğü görüşüdür (Accel Team.Com, 2001). Bu nedenle, örgütlerin insan ilişkileri yaklaşımını benimsemekte çok zorluk çekmediği ve kolayca benimsediği fikri ileri sürülebilir. Hatta örgütler bu yaklaşımı, özünde insana yönelik bir yatırım olmasından dolayı kolayca uygulayabilmiştir. Baransel (1979), “insan ilişkileri” yaklaşımının; motivasyon, önderlik, grup davranışı, kişiler arası ilişkiler ve haberleşme gibi mikro konularla gelişmeye başladığını ve daha sonra biçimsel ve biçimsel olmayan örgüt, sosyal ve teknik sistemler arasındaki etkileşim, birey ve örgüt bütünleşmesi gibi makro konu ve sorunlar üzerine eğilerek olgunlaştığını söylemektedir. Hatta bu yaklaşımın giderek "örgütsel davranış yaklaşımı" ve "sanayide hümanizm" akımına dönüştüğü yönünde de iddialar vardır (Wren, 1972, s.442).

Örgüt içerisinde çalışan kişinin gerek maddi gerekse manevi ihtiyaçlarının tatmininin sağlanması ve örgütle ilgili amaçlarının gerçekleştirilmesi için uygun olanakların yerine getirilmesi, insan ilişkileri yaklaşımının temel felsefesidir. Bu nedenle Davis (1977, s.12), örgüt içerisindeki çalışan bireylerin birbirinden farklı olduğunu, insanın bir bütün teşkil ettiğini, insan davranışlarının belirli nedenlere bağlı olduğunu, ancak insanın 
diğer üretim faktörlerinden farklı bir yapıda biçimlendiğini, örgütlerin bir sosyal sistem niteliği taşıdığını ve insanın örgüte, örgütün de insana ihtiyacı olduğunu savunmaktadır.

Baransel, neo-klasik yönetim düşüncesinin öngördüğü insan modelini, bu ekolün önde gelen isimlerinden Elton Mayo'nun gerçekleştirdiği Hawthorne Araştırmaları sonucuna bağlı olarak şu şekilde sıralamaktadır:

1-İnsan, esas itibarıyla sosyal intiyaçlarla motive olur. Ayrıca, iş arkadaşları ile ilişkileri, temel özdeşim duygusunun gelişmesini sağlar.

2-Sanayi devriminden bu yana, işlerin ileri derecede ussallaştırılması işlerin, işçiler için anlam kaybına neden teşkil etmiştir. Bu anlam kaybının sosyal ilişkilerle giderilmesi eğilimi ortaya çıkmıştır.

3-Çalışan kişiler, yönetimin denetimi ve ödüllerinden çok, çalışma grubu arkadaşlarından gelen etkilere karşı duyarlıdır.

4-Yönetime karşı duyarlılık, nezaretçinin, çalışan kişilerin "sosyal" ve "kabul edilme" intiyaçlarını tatmin derecesine bağlıdır (Baransel, 1979, s.224).

İnsan ilişkileri yaklaşımını "davranışsal örgüt teorisi" olarak niteleyen Koçel (2001), bu yaklaşımın ana fikrini Ross ve Murdick'in (1977) makalesinden alıntı yaparak açıklamaktadır. Koçel'e göre davranışsal örgüt teorisi, örgüt yapısı içerisinde çalışan insan unsurunu anlamak, onun yeteneklerinden en üst düzeyde yararlanmak, örgüt yapısı ile insan davranışları arasındaki ilişkileri incelemek, örgüt içerisindeki sosyal grup oluşumlarının nedenini araştırmak ve yöneticiye kullanabileceği yeni araç ve kavramlar yaratmak amacını güder.

Geleneksel yaklaşımların aksine insan ilişkileri teorisi insanı, "ekonomik bir varlık" olarak değil "sosyal ve psikolojik bir varlık" olarak kabul etmekte ve 
bireyi işe motive eden en güçlü güdünün ekonomik değil; sosyal ve psikolojik olduğu tezini savunmaktadır (Sabuncuoğlu ve Tüz, 1995, s.16).

Örgütsel analizlerin yapılmasında teknik, ekonomik ve yapısal unsurların insanın çıkarlarına yönelik olarak odaklandığı yaklaşımını McGregor (1960, s.40) “.örgütler içinde çalışan kişiler kendi amaçlarını gerçekleştirirken, örgüt amaçlarının gerçekleşmesine de hizmet eden bir ortam yaratırlar" şeklinde açıklamaktadır. McGregor'a göre, klasik kuramın koşullarına sadık kalan yöneticiler, iş görene saygıyı, kendi kendine saygıyı, arkadaşlarının kendisine saygısını ve başarı kazanma olanaklarını sağlayamaz. Çünkü klasik kuram, katı mantığı ile insanı, teknik ilkeler ve basit ekonomik güdülerle hareket eden bir robottan farklı tutmamaktadır. İnsanı duygu ve düşünceleri ile hareket eden bir varlık olarak görmemektedir. Buna karşın insan, iş arkadaşlarını sever ve örgütü benimserse, yönetim yetki ve sorumluluğunu da yüklenmeye hazırdır (Eren, 1996, s.33).

McGregor'un X teorisi olarak ortaya koyduğu ve insana yönelik bu yaklaşımların alternatifi olarak bir de $Y$ kuramı bulunmaktadır. Bu kuram, yine McGregor'un geliştirdiği klasik yönetim anlayışının insana ilişkin yapmış olduğu saptamalara bir alternatif olarak gerçekleştirilmiş olup McGregor'un deyimi ile "bilimsel ve örgütsel amaçların kaynaştırılması" şeklinde ifade edilmektedir.

Bu teoriye göre, insanlar işi ve iş arkadaşlarını severse, kendi kendini yönetme ve denetim yollarını kullanarak örgüte daha yararlı olmaya ve hizmet etmeye çalışır. Örgütsel amaçların gerçekleşmesinde başarıya ulaşan insanlar, takdir edilme yolu ile ödüllendirilmelidir. İnsanların sorumluluktan kaçınması, 
doğuştan gelmez bilâkis elverişli koşullar sağlandığı takdirde normal insan, sorumluluğu kabul etmekle kalmaz; onu aramaya da başlar (Eren, 1996, s.34).

Örgütlerde insan ilişkileri yaklaşımından söz ederken unutulmaması gereken bir diğer husus, Chris Argyris'in (1996) geliştirdiği olgunlaşma kuramıdır. Argyris'e göre kişinin sorumluluk alanının arttırılması onu olgunlaştırmakta ve dolayısıyla işletmedeki verimliliğin artmasına neden olmaktadır. Argyris, örgüt çalışanlarının üstlerine bağlı olma ve örgütlerin çalışanlara kendilerini kontrol etme şansı tanımaması gibi nedenlerden dolayı kişinin olgunlaşamadığını belirterek, örgütlerin çalışanların sürekli denetlenmesi gerektiği yönünde görüşlerinin olduğunu belirtmektedir (Eren, 1996, s.36). Aslında bu yaklaşımla insan, örgüt tarafından pasif hale getirilerek davranışları kısıtlanmaktadır.

Argyris'in de üzerinde önemle durduğu gibi “insan” faktörü, aslında örgütün verimliliğinin arttırılması yönünde kullanılan bir aracı olarak ifade edilmiştir. Bu saptamadan yola çıkarak gerek McGregor'un Y teorisinin, gerekse Argyris'in "olgunlaşma" kuramının, bundan önceki yaklaşımlar da dikkate alındığında (örneğin Taylor'un "bilimsel yönetim kuramı" veya Weber'in "bürokrasi modeli”) teknik verimliliğin önem kazandığı örgüt yönetimine yeni bir boyut getirmiş oldukları söylenebilir.

Baransel (1979, s.222), insan ilişkileri yaklaşımının disiplinler arası bir nitelik taşıdığını ve alt disiplin alanı olarak sosyolojiden, psikolojiden ve sosyal psikolojiden etkilendiğini belirtmektedir. Bununla birlikte yazar, sözü edilen disiplinlerin katkıları ile insan ilişkileri yaklaşımının giderek bilimsel bir nitelik kazandığını ifade etmektedir ve daha sonra felsefi temellere dayandırılarak 
"örgütsel davranışa" dönüştüğü yönünde açıklamalarda bulunmaktadır. Bu görüşün temelini Scott, 1967 yılında yazdığı "Organization Theory" adlı kitabında atmıştır. Scott, insan ilişkileri yaklaşımını, insanın motive olabileceğini ve her zaman rasyonel olamadığını, insanların birbirine bağımlı olmasından dolayı bireysel davranışlarının iş yerindeki sosyal koşullarla açıklanması gerektiğini ve yöneticilerin de iyi bir uygulamacı olabilecek şekilde eğitilebileceklerini söylemiştir ki, bu bulgular psikolojinin katkılarıdır. Sosyoloji ise, iş yerindeki sosyal ortamın sadece grup yönetimi tarafından oluşturulmadığı ve grup üyelerinin de sosyal ortamın bir parçası olduğu; örgütlerin birbirini karşılıklı etkileyen sosyal bir sistem olarak kurulması gerektiği; iş yerindeki biçimsel olmayan örgüt ve kliklerin biçimsel örgütlerden etkilendiği ve işin gerektiği rollerin mevcut kişisel ve sosyal iş fonksiyonları nedeni ile iş tanımlarında belirlenenden çok daha karmaşık olduğu gibi bulgularla insan ilişkileri yaklaşımına katkıda bulunmuştur. Son olarak sosyal psikoloji de, insanların örgüt amaçlarına kendi amaçları imiş gibi bakması gerektiği, örgütsel bilginin örgütün ussal ve ekonomik bir biçimde işleyişini sağladığı gibi çalışan kişilerin his ve duygularını da naklettiği; örgüt çalışanlarının örgüt kararlarına katıımının örgütün moral ve verimliliğini arttıracağı ve sağlam teknik kararlar ve işbirliği için ekip ruhunun önemli olduğu yönünde katkılarda bulunmuştur (Scott, 1967, s.35).

İnsan ilişkileri yaklaşımı insanı hem birbirinden farklı psikolojik ve biyolojik bir varlık olarak görmekte, hem de davranışları ile örgüt yapı ve işleyişini etkileyen ve sosyal bir grup içerisinde yer alan psiko-sosyal bir varlık olarak 
görmektedir. Bu ekolün yönetim düşüncesine getirdiği genel katkılar, aşağıda ifade edilmiştir.

Yaklaşımın, klasik yönetim düşüncesi boşluğunu dolduran katkılarından ilki, klasik yönetim düşüncesinin otoriter görüşlerine karşı, demokratik ögelerin ve insan öğelerinin ön planda yer almasıdır. (Baransel, 1979, s.285). Bu anlamda; antropoloji, sosyoloji ve psikoloji dallarının örgütlerin verimliliğinin arttırımasında etkili olabilecek sonuçlar sağlayabileceği açıktır.

İnsan ilişkileri yaklaşımı, bilimsel incelemeler ve araştırmalara dayandırıldığı için, pratik açıdan, yöneticinin yönetimi altındaki insanlarla olan ilişkilerinde başarılı olmasını sağlayacak "klinik bir tahlil" de ortaya koyabilecektir (Baransel, 1979, s.285).

İnsan ilişkileri akımını açıklarken gözden kaçırılmaması lazım gelen önemli bir husus daha bulunmaktadır. Onaran'ın da dikkat çektiği bu konu, “insan ilişkileri” akımının günümüze getirdiği anlayış biçimi ile ilgilidir. "İnsanların toplumsal gereksinmelerini karşılayarak onları daha verimli çalışmaya yönlendirmek" şeklinde algılanan bu anlayış biçimi, "günümüz koşullarında daha çok alt kademe yöneticileri için iş görenlere nasıl davranılacağını gösteren bir eğitim aracı" şeklinde yorumlanmaktadır (Bennis, 1967; aktaran: Onaran, 1971, s.17).

Tüm bu açıklamalar ışığında, insan ilişkileri yaklaşımının kısaca, klasik yönetim anlayışının unuttuğu insanın sosyal ve psikolojik yönünü yeniden gündeme getirdiği söylenebilir. Buna paralel olarak yeni yaklaşım, insanın iş yaşamında her zaman rasyonel olamayacağını, sadece ekonomik getirilerle çalışanın motivasyonunun gerçekleşemeyeceğini, insanın örgüt içerisinde 
verimli olabilmesi için bireyler arası ilişkilerin son derece önemli olduğunu, sosyal gruplaşmaların örgütün etkinlik kazanmasında hatırı sayılır bir kademede yer aldığını ve örgüt çalışanının kendi kimliğinin değil; ait olduğu örgüt içindeki sosyal grubun kimliğinin önem kazandığını savunmaktadır. İşbirliği ve yardımlaşma, insan refahı, gruplara dayanan kontrol ve örgüt çalışanlarının otokontrolü, ayrıca örgütte demokratik bir yönetim süreci, basık yönetim yapısı, ekonomik ve sosyal teşviklerle sağlanan mükafat sistemi olması, bu yaklaşımın en önemli temel kavramları arasında sıralanabilir.

\section{Bilgi Yönetiminde İnsan Faktörü}

"Elinde bilgisi olan örgütler, bilgiyi taktiksel amaçlarını gerçekleştirmeye yönelik olarak kullanabilirler"; (Blog, 15 Ocak 2002:1) fakat bilgiyi yönetebilmesi için de mutlaka insana gereksinme vardır. Bu gereksinme penceresinden bakıldığında, öncelikle bilgi yönetimini gerçekleştirecek insana ilişkin temel yaklaşımlar gözden geçirilecektir. Daha sonra bilginin varlığına ve tanımına ilişkin açıklamalar bağlamında çeşitli bilgi düzeylerinden, yani bilginin hiyerarşik yapılanmasından bahsedilecektir. Daha sonra ise, "bilgi yönetimi"ile enformasyon yönetimi arasındaki temel farklar açıklanacaktır.

Bilgi yönetiminde insan faktörü denildiği zaman ilk olarak, yönetimde çalışanların motivasyonu, özlük hakları, tazminat, insan-teknoloji etkileşimi sayesinde oluşan sorunlar ve yenilikler, üretkenlik/verimlilik ve inovasyon, takım çalışmaları ve yarattığı potansiyel sorunlar ile sakıncaları gibi hususlar akla gelmektedir. Aslında "çalışan" olmanın getirdiği yaklaşımlardan pek de farklı olmayan bu özellikler, günümüzde örgütsel öğrenme alanı içerisine girmektedir. Örgütsel öğrenme alanı içerisindeki "bilgi yönetimi ve liderlik" alt konusu, bu 
çalışmada bilgi yönetiminde "insan" faktörü üzerine vurgu yaptığımız noktayı oluşturmaktadır. Çünkü, bir örgütün bilgi yönetim sürecinin devamlılığı, o örgütün öğrenme aşamasına gelip gelmediği ile doğrudan ilişkilidir. Bilgi yönetiminin örgütlerde etkili ve kalıcı olması için örgütlerin "örgütsel öğrenme" süreci içerisine girmeleri gerekmektedir. İşte bu nedenlerle, anlatımı sona erdirmeden önce örgütsel öğrenme konusuna kısaca değinmek gerekecektir.

İşletmenin örgütsel bir süreç olarak varlığının bilgi yönetimine dayandırıldığı son kısım özetle, örgütün devamlılığının örgüt içerisinde çalışan insanların hafızalarındaki bilgi haritalarına bağlı olduğunu ortaya koymaktadır.

\section{Kavramsal Olarak Bilgi Hiyerarşisi}

Bilgi etrafında düşünüldüğü ve bilginin özellikle işletmelerdeki rolünün derecesini anlamaya çalıştığımız zaman, Nonaka'nın dediği ve Japon şirketleri olan Honda, Canon, Matsushita, NEC, Sharp ve Kao'da gözlemlendiği gibi “yeni bilginin üretilmesi yönetiminde karşı tek biçim bir yaklaşım içerisinde olunması gereğidir" (Nonaka, 1991, 1).

Çeşitli bilim dalları bilgiyi farklı şekillerde tanımlamaktadırlar. Fakat, bilginin ne olduğu açıklanmadan önce "bilgi hiyerarşisi" üzerinde durularak yönetim alanına giren her türlü şeyin veri mi, enformasyon mu, yoksa bilgi mi olduğu somut olarak ayırdedilmelidir. Edward Walz (1998), "Information Warfare" adlı kitabında bilgiyi Şekil 1'de görüldüğü gibi kategorize etmiştir! 


\begin{tabular}{|c|c|c|}
\hline Soyutlama Düzeyi & Bilgi Süreci Akışı & Süreçler \\
\hline $\begin{array}{l}\text { FiKiR OLUŞTURMA } \\
\text { Bilgi tesirli bir şekilde uygulanır }\end{array}$ & $\begin{array}{c}\text { Uygulama } \\
\text { Arzulanan bir hedefe veya nihai } \\
\text { duruma ulaşmak için bir biçimde } \\
\text { yürütülecek olan bir plan veya } \\
\text { eyleme yönelik bilgi uygulama } \\
\text { süreci }\end{array}$ & $\begin{array}{l}\text { *Liderlik } \\
\text { *Karar Alma } \\
\text { *Karara Yardımcı OIma }\end{array}$ \\
\hline $\begin{array}{l}\text { BÍLGi } \\
\text { Enformasyon anlaşılır } \\
\text { çıkarma ve açıklanır }\end{array}$ & $\begin{array}{c}\text { Anlama } \\
\text { Bu iliş̧ileri açıklamak için bilgi } \\
\text { grupları ve sentezleme modelleri } \\
\text { süreci arasındaki kapsayıcı, statik } \\
\text { ve dinamik ilişkiler süreci }\end{array}$ & $\begin{array}{l}\text { *Sonuç } \\
\text { *Tümevarım } \\
\text { *Tümdengelim } \\
\text { *Kaçırma } \\
\text { *Muhakeme etme } \\
\text { *Kuşkucu yönetim }\end{array}$ \\
\hline
\end{tabular}

\section{ENFORMASYON}

Veri, içeriğe, indekse ve organizasyona yerleşir

VERi

Ölçüm ve gözlem

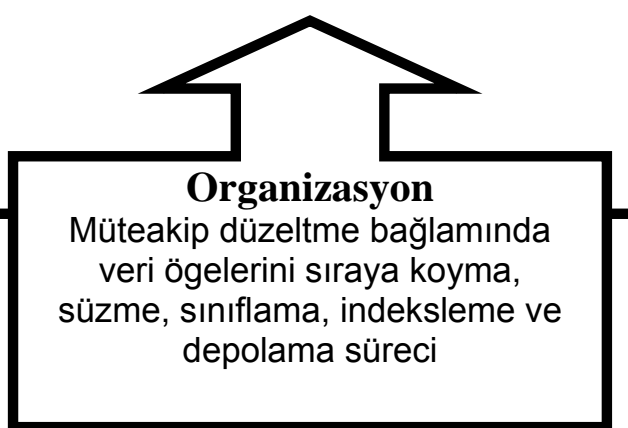

*Sıraya koyma

*Korelasyon ve ilişki kurma

*Dışdeğerbiçim

*Çatışmama durumu

*Sürecin öncesi

*Boyut belirtme

*Süzme

*Indeksleme

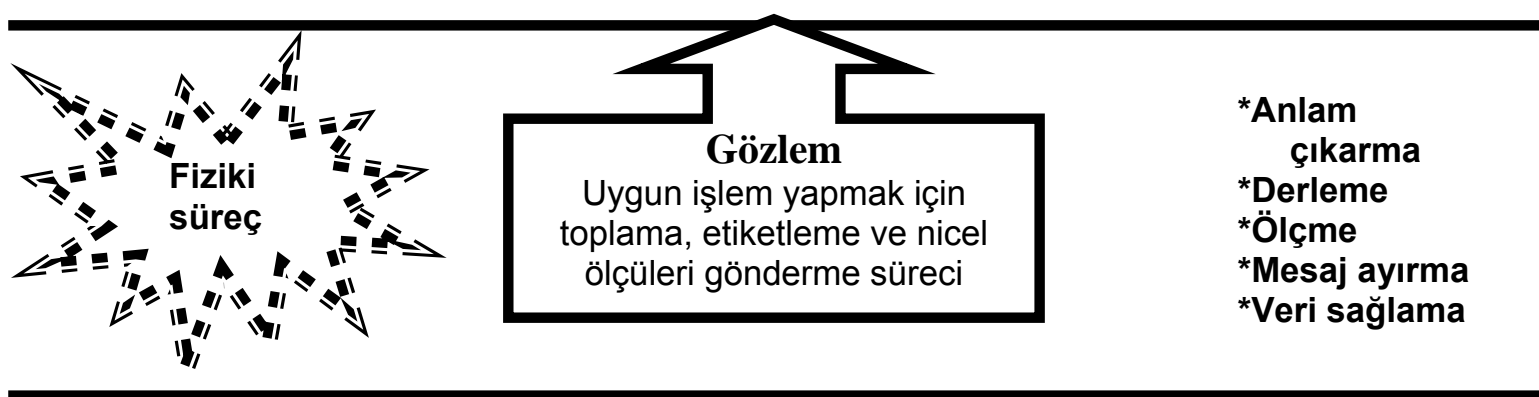

Şekil-1. Bilgi Hiyerarşisi (Kaynak: Walz, E. (1998). Information warfare: Principles and operations. London: Artech House, s.56).

Tabloyu yorumlamak yerine tablo üzerinde bir örnek vermek gerekirse, özel işletmeler için pazarla ilgili olan veya diğer ekonomik ölçümler gözlem yolu ile elde edilebildiği için veri (data) sayılırken, bunların analizleri ve pazarın ekonomik davranış modellerinin anlaşılır bir yapıya dönüştürülmesi 
enformasyon (information) ve genel manada ekonomi, pazar değerlendirmeleri ve stratejik planlar uygulamaya yönelik olarak yapılan hazırlıklar bilgi (knowledge) sayılmaktadır. Son kategoride, tüm bu aşamaların gerçekleşmesi ve şirketin başarıya ulaşması ise şirket ile ilgili bir fikir oluşturduğundan dolayı fikir oluşturma (wisdom) olarak adlandırılmaktadır (Sağsan, 2002, s.217).

Bu şekle benzer bir diğer taksonomik yapılandırmayı da Barutçugil (2002, s.57-60) yapmıştır. Yazar, bilgi spektrumunu dört aşamada ele almıştır. Birinci aşama veridir ve kurumsal amaçlara bağlı olarak işlemlerin yapılandırılmamış bir biçimde kaydedilmesi şeklinde tanımlanmaktadır. İkinci aşama ise enformasyondan oluşmaktadır. Bu, bir bakıma düzenlenmiş veri şeklinde ifade edilebilir. Üçüncü aşama da, enformasyonun kişiselleştirilmiş ve özümsenmiş hali olan bilgidir. Bilgi, insanların beynindedir ve tüm yaşamları boyunca öğrendiklerinin ve deneyim yolu ile kazandıklarının toplamıdır. Akıl ise bu spektrumun son aşamasını oluşturmaktadır ve bütünleştirilmiş bilgi veya bir bilgiyi başka bir alana taşıyabilme ve yararlanabilme yeteneği olarak bilinir.

Çalışmada, sıklıkla üzerinde durulan 'bilgi yönetimi' kavramındaki "bilgi" (knowledge) terimi, enformasyon (information )veya veri (data) düzeyinde değil; bilgi anlamında ele alınmıştır. Çünkü, örgütte çalışanların yargıları, herhangi bir olay karşısında düşündükleri, diğer çalışanlarla tartışmaları yoluyla ortaya çıkan sonuçlar, deneyimleri sonucu elde ettikleri ve çalışanların kişisel değerleri ve inançları bilginin kendisini oluşturmaktadır

\section{Bilgi Yönetiminin Anlamı ve Bilgi Yönetimi Alanı}

Gerek klasik, gerek neo-klasik, gerekse stratejik yönetim düşüncelerinin temelinde yatan bilgi unsuru gelecekte hem teknolojik hem de yönetsel anlamda 
örgütleri yönlendirecektir. Bu nedenle, bilgi yönetim çalışmaları 21. yüzyıl toplumlarında giderek artan bir önem sahiptir ve bir disiplin olarak literatürde yer almıştır.

Bilgi yönetimi, kavramsal olarak farklı yazarlar tarafından farklı şekillerde tanımlanmıştır. Kimileri bilgi yönetimini bilgi toplayıp derleme ve bunları, kişisel tecrübeleri ile birleştirerek örgüt çalışanlarının istifadesine sunmak şeklinde tanımlarken (Karakaş, 2002) kimileri de örgütlerdeki bilgi yönetimi çalışmalarını 'gelecekteki potansiyel sermaye yatırımı' olarak görmektedirler. Sermaye açısından bakıldığı zaman bilgi, 'rekabetçi piyasada şirketlerin ellerinde bulundurdukları en değerli varlık' şeklinde ifade edilebilir. Bu bakış açısıyla hem şirketin müşteri potansiyeli, hem şirket çalışanları hem de örgütün yapısı bir tür kapital/sermaye olarak değerlendirilmektedir.

Unutulmaması gereken önemli bir nokta, bilgi yönetiminin enformasyon teknolojileri sayesinde ön plana çıktığıdır. Bilgi yönetimi araçsal gelişimini enformasyon teknolojilerine borçlu olmakla birlikte, enformasyon yönetiminden farklı bir anlamı olduğu (Keskin ve Kalkan, 2002, s.5) daha önce de ifade edilmişti. Enformasyon yönetimi, daha ziyade bilginin saklandığı fiziksel formların yönetimi şeklinde algılanırken; aynı zamanda sözsüz yahut kayıtsız bilgilerle ve gözlemlenebilir, sözlü veya açık olmakla birlikte sistematik olarak organize olmamış durumlardaki bilgiyle de ilgilenmektedir (David ve Klobas, 2000, s. 421). Yani bilgi yönetimi daha genel anlamda, içerisine enformasyon yönetimini de kapsayacak bir disiplin olmakla birlikte veri, enformasyon, bilgi ve akıl oluşturma sürecindeki teknolojik çalışmaları da içermektedir. 
Bilgi yönetimi, ister örgütlerde enformasyon teknolojileri kullanımının artmasıyla bilgi akış sürecini kapsayan bir yönetim olsun, isterse şirketlerin sermaye oluşumlarının bir parçası durumunda bulunsun, 21. yüzyıl kurum ve şirketlerinde gerek bireysel gerekse örgütsel düzeyde son derece kritik bir noktada yer almaktadır. Hatta örgütlerin gelecekteki varlıklarının bilgi yönetimine bağlı olduğunu iddia eden çalışmalar bile bulunmaktadır.

Örgütler için bu kadar önemli bir pozisyonda bulunan bilgi yönetiminin insana/çalışana dair yaklaşımlarını izah etmek ve bu yaklaşımı insan ilişkileri akımındaki insan olgusu ile karşılaştırmak gerekir.

\section{Bilgi Yönetiminin İnsan Yaklaşımı}

Örgütte "veri ve enformasyona değer katarak, onları bilgiye dönüştüren insandır. Bilgi yönetimi için özel olarak oluşturulmuş görevlerde belirli sorumluluklar çerçevesinde çalışan elemanlar" (Davenport ve Prusak, 2001, s.155) birçok sıfatla nitelendirilmektedirler ve örgüt içerisinde oldukça önemli pozisyonlarda yer almaktadırlar. Örneğin, bilgi yöneticisi, bilgi müdürü, bilgi işçisi, bilgi proje yöneticisi, vb. gibi.

Entelektüel sermaye açısından düşünüldüğünde, bilgi yönetimi, "insan kaynaklarını" temel değerlendirme noktası olarak almaktadır. Bu yaklaşıma göre insan kaynaklarına yapılan yatırım, aynı zamanda bilgi yönetimine yapılan yatıım olarak da açıklanabilir. Nitekim, Bontis; insan kaynaklarını bilgi yönetiminin bir halkası olarak ifade etmekte ve bilgi yönetimi sürecine dahil olan insanın "motive ve tanzim edilmesi, ödüllendirilmesi ve tanınması" gerektiğini söylemektedir (Svetvilas ve Chuleenan, 2001, s.1). İnsan ilişkileri yaklaşımının 
bir başka açıdan değerlendirilmesi şeklinde yorumlanabilen bu açıklamalar, bilgi yönetiminin insan ögesine verdiği önemi açık bir şekilde ortaya koymaktadır.

Bilgi yönetiminin insana verdiği değer, bilgi yönetiminin temel prensipleri içerisinde yer alan "bilgi dinamik bir sosyal süreçtir" sözünden de kolaylıkla anlaşılmaktadır. Bu prensip, "işletmelerdeki bilginin diyalog, görüşme ve eleştiriler vasıtasıyla yaratıldığını, insanların bir arada bulundukları sürece bilginin üretildiğini ve bilgi yöneticilerinin bilgiyi ellerinde tutma, paylaşma ve uygulama süreçlerinin tasarlanması ve uygulanması için yine bilgiyi üreten insana ihtiyaç duyduğunu" (Alle, 1997, s.26) söylemektedir.

Bilgi yönetimi, örgüt içinde çalışanların ilişkilerinin sağlıklı bir şekilde yürütülebilmesi açısından örgüt verimliliğine destek vermektedir. Resmi olmayan ilişkiler sayesinde çalışan düşüncelerinin paylaşılmasının, örgütteki bilgi akışını son derece kolaylaştırdığı söylenebilir. Hatta, çalışanlar arasında gerçekleşen dedikodu ve sohbet niteliğindeki diyaloglar, örgütün geri bildirim almasında büyük rol oynamaktadır. Ayrıca, gerek örgüt düzeyinde gerekse çalışanlar arasında dolaşan bu bilgilerin, çalışanların psikolojik durumunu dışa yansıtma niteliği taşıması dolayısıyla bir açıdan rahatlamalarını da sağlamaktadır ki, bu durum, insan ilişkileri yaklaşımının temellerinden birisi olan "çalışanların psikolojik olarak rahatlatılması" görüşünü destekler niteliktedir. İnsan ilişkileri ekolünün bilgi yönetim sürecinin gerçekleşmesi noktasında yaptığı bu katkıyı göz ardı etmemek gerekir.

Bilgi yönetiminin insan davranışları ve verimliliğine olan etkilerini değerlendirirken, etkin bir bilgi yönetiminin teknoloji, örgüt ve insan sentezlerine yönelik olduğunu unutmamak gerekir. Bu bağlamda, bilgi yönetimi alanında 
üretilen ve verilen hizmetlerin, gerçek anlamda insan ihtiyaçlarını karşılayacak ve insan değerlerini kucaklayacak bir nitelikte olması gereklidir.

\section{İşletmeler Açısından Örgütsel Bir Süreç: Bilgi Yönetimi}

“Insanlar arasında iletişim yoluyla enformasyon akışı, bilginin yaratılmasını sağlar" (Barutçugil, 2002, s.58). O nedenle bilgi yönetimi kavramındaki bilginin "bilgi" olabilmesi için, örgüt çalışanları arasındaki ilişkilerin örgüt tarafından desteklenmelerini sağlayacak politikaların oluşturulması gerekmektedir. Aslında, örgüt çalışanlarına ait fikirlerin açıklanmasının ve örgüt yararına kullanılmasının bir diğer yolu da, zihinlerdeki bilgi haritalarının ortaya çıkarılmasıdır. Her çalışanın kendisine has ve aklında gelişmiş olan bir bilgi haritası vardır. Bu bilgi haritalarının ortaya çıkabilmesi için çalışanların sohbet ortamında söyleyecekleri sözler büyük önem taşımaktadır. Bu yöntem sayesinde elde edilecek bilgi haritası ögeleri ise, işletmenin genel anlamda oluşturacağı bilgi yönetiminin bir parçası olacaktır.

Nitekim, "bilgi haritası da, gözlem edinenler tarafından onların zihinlerindeki ve geçmiş tecrübelerindeki çok yönlü detayların farklılaşarak bilginin öğrenilmesine imkan sağladıktan sonra var olan görsel görüntülerden oluşmaktadır. Bu görüntüler, metin, hikaye, grafik, model ve sayı niteliği taşıyabilmektedir. Ayrıca, bu haritalar kesin bilgiye sahip kaynaklar kadar detaylandırılmış bağlantılara da hizmet etmektedirler (Vail ve Edmond, 1999, s.2). Aslında bilgi haritası, örgütte çalışan bireylerin sadece örgüt ile ilgili olarak zihinlerinde oluşmuş bilginin haritası anlamına da gelmektedir.

Örgütlerdeki insan ilişkilerinin bilgi yönetimi ile olan ilgisi değerlendirilirken bilgi teknolojilerinden de bahsetmek gereklidir. Her ne kadar, 
örgütlerde, gerek bilginin üretilmesi, gerek yayılması, gerekse de pazarlanması veya hizmete sunulması iyi bir yönetim becerisi istese de; çoğu örgüt bu beceriye, günümüz bilgi ve iletişim teknolojileri ve üstünlükleri sayesinde ulaşmaktadır. Ancak bu teknolojilerin gelişimiyle örgüt içerisindeki sözlü iletişimin olumsuz yönde etkilendiği gerçeği de göz ardı edilemez.

Bilgi yönetimi süreci, örgütlerde genellikle teknoloji-yoğun kullanımı nedeniyle, bir yandan örgüt içi çalışanlar arasında diğer yandan da örgüt çalışanları ile yöneticiler etrafında son derece önemli bir işleve sahiptir. Öte yandan çalışanların söylemleri ve paylaştıkları ile örgütün çalışanlardan beklentisi, bu noktada örgütün verimliliği açısından bir denge unsuru oluşturmaktadır. Sonuçta, bu denge sayesinde örgüt, aynı zamanda bilgi yönetiminde bir "eşitlik seviyesi" de yaratmaktadır.

Yukarıda değinildiği üzere, bilgi teknolojilerini sıkça kullanan örgütler, örgüt içindeki insan ilişkilerinin gelişmesine sekte vurmuştur. Bu geriye doğru gidişat, örgüt içindeki bilgi yönetimini de insan ilişkileri açısından olumsuz yönde etkilemiştir. Örgütlerdeki çalışanlar arası ilişkiler; bilgisayarlar ve buna bağlı diğer bilgi teknolojileri araçlarının sık kullanımı nedeniyle yok olma tehlikesi ile karşı karşıyadır. Bu tehdidin bir sonucu olarak, neo-klasik yönetim anlayışının örgütlere girmesi zorunluluğu kaçınılmaz hale gelmiştir.

Yönetsel faaliyetlerini ve verimliliğini bilgi ve iletişim teknolojileri ile buna bağlı araçlara dayandıran örgütlerdeki insan ilişkileri çıkmazdadır. Bu çıkmaz, planlı ve insan ilişkilerini geliştirme ve iyileştirme amacına yönelik olarak oluşturulacak iyi bir bilgi iletişimi ve yönetimi sayesinde aşılabilir. Verinin enformasyona, enformasyonun da bilgiye dönüşmesi ve dolayısıyla örgütlerin 
bu bilgiden kâr veya fayda elde edebilmesi (yani kısaca varlığının devamı) için örgüt içi ve örgütler arası insan iletişimi süreci etkili bir biçimde uygulamaya konulmalıdır. Aksi takdirde, davranışsal ekolün belirlediği "sosyal insan" ve klasik yönetim anlayışının tasvir ettiği "ekonomik insan" modelleri, yerlerini “teknolojik insan"a bırakacaktır.

Örgüt çalışanları arasındaki ilişkilerin düzeyi, örgütsel iletişimin yoğunluğu ve süresi; işletme içindeki bilgi akışının üst düzeylere kadar ulaşmasında etkilidir. Günümüzde, klasik yönetim anlayışını benimsemeyen örgütler, bir taraftan verimliliği arttırma yolunda çalışanlara baskı yaparken; diğer taraftan da bilgi ve iletişim teknolojileri yüzünden gerileyen insan ilişkilerini ve örgüt içi işbirliği ve takım çalışmasını göz ardı etmektedirler. Bu tür örgütlerde, bilgi yönetimi kısır bir döngü içerisinde kalmakta ve gelişememektedir. Geri bildirimlerin alınmadığı, yönetim anlayışının yazılı ve katı kurallara bağlı olduğu örgüt içi iletişimsizliğin sıkça yaşandığı, işbirliği faaliyetlerinin giderek azaldığı ve ortak sahiplenme dürtüsünün olmadığı bu tür örgütlerde bilgi, sadece örgütün (çalışanın değil) çıkarına hizmet eden bir araç olarak nitelendirilebilir. $\mathrm{Bu}$ anlayış ise, bilginin bir yönetim süreci içerisine girmesini engellemektedir. Yani, yöneticinin sert tutum sergilediği, çalışanların psikolojik olarak rahatlatılmadığı veya sosyal bir varlık olarak değil de "ekonomik bir varlık" olarak algılandığı ve sadece örgütsel verimliliğin ön planda olduğu bu örgütler, bilgi yönetim sürecinin yararlarından mahrum kalmaktadırlar. Bu durumun doğal bir sonucu olarak da, örgütsel verimlilik ve devamlılık her hâlükârda zayıflama sürecine girecektir. Bilgi yönetimi sürecinin yapı taşını oluşturan iletişim, bilgi yaratma ve bilgi paylaşma işinin dayandırılabileceği tek temeldir. Eğer bir 
örgütte etkili bir iletişim sağlanamamışsa, işbirliği, ortak sahiplenme ve birlikte çalışabilme olanakları gerçekleşemez. Bu açıdan örgütsel iletişimin yönü, insan ilişkilerinin geliştirilmesine doğru çevrilmelidir. Böylelikle örgüt, hem ortak bir hareket tarzı belirleyebilir, hem de kolektif iletişim kanallarının kurulabileceği bir yapı oluşturabilir.

İşletmeler açısından örgütsel süreçlerden bahsederken, bireysel düzeydeki bilginin örgütsel düzeye nasıl eriştiğinden de söz etmek gerekir. Örgütsel bilginin yaratılması olarak ifade edilebilen bu süreç, örgütlerde bireysel düzeyde üretilen bilgi kapsamının genişlemesine imkan sağlayacak ortamların yaratılması şeklinde de ifade edilebilir. Bu ortamın genişlemesi için, öncelikle çalışanların bütünleşmesi ve örgütteki sosyalizasyon sürecine katılımlarının teşvik edilmesi gerekir (Barutçugil, 2002, s.82). Yani öncelikle bireysel düzeydeki bilginin içeriği zenginleştirilmeli ve örgüt tarafından desteklenerek bu yolla örgüt içi grupların oluşturulması sağlanmalıdır. Daha sonra, bu gruplar arasında birliktelik sağlanarak sosyalleşme gerçekleştirilmeli, böylece bireysel düzeydeki bilgi örgütsel düzeye çıkartılmalıdır. Tabii ki bu işlemler esnasında, bilginin içsel ve dışsal iletişim noktaları gruplar tarafından esnekleştirilmeli ve desteklenmelidir. Sonuçta, bireysel düzeydeki bilgi grup seviyesine, oradan da örgütün amacına uygun hale getirilebilmektedir.

Bu yaklaşımlar aslında Nonaka'nın (1999, s.33) "Bilgi yaratan şirket” adlı makalesindeki "yeni bilgi yaratılması bir uzmanlık alanı değildir; bir davranış biçimi, aslında bir varoluş biçimidir ve bu çerçevede herkes bilgi işçisidir, yani girişimcidir" sözünü çağrıştırmaktadır. Aslında örgütteki bireylerin davranış 
biçimleri genel olarak örgütün davranışını etkilediği için, "örgütsel bilginin niteliğini yine bireysel bilgi ve davranışlar belirlemektedir" yorumu yapılabilir.

\section{Örgütsel Öğrenme}

Varılan bu noktada, "bilgi yönetiminde başarılı olabilmek için gerekli süreç ve sistemi geliştirmede örgütler ne gibi yol ve yöntemler izlemelidir" sorusuna yanıt aranabilir. Örgütlerdeki bilgi yönetim sürecine imkan veren; bilgi yönetiminin devamlılığını sağlayan ve etkin kullanımını gerçekleştiren unsur olarak örgütsel öğrenme, bilgi yönetimi açısından büyük önem taşımaktadır. Fakat; bir önceki bölümde vurguladığımız gibi; örgütlerdeki "bilgi yönetim sürecinin oluşmasında" örgütsel öğrenme anahtar pozisyonda yer almaktadır. Örgütsel bilgi yönetim sürecinden; örgütlerdeki verinin enformasyona, enformasyonun bilgiye ve oradan da örgütsel belleğe dönüştürülmesinde devamlılığın sağlanması kastedilmektedir.

\section{Örgütsel Öğrenme Kavramı}

Örgütsel öğrenme kavramı çeşitli dallardaki (eğitimciler, psikologlar, sosyologlar ve örgüt teorisyenleri gibi) bilim insanları tarafından farklı şekillerde tanımlansa da; çalışma konusunun örgüt teorisi çerçevesinde değerlendirilmesinden ötürü, bu bağlamda tanım verilecektir. Bazı yazarlar örgütsel öğrenmenin "bireysel öğrenme ile örgütsel öğrenme arasında kurulacak bir köprü sayesinde gerçekleşeceğini" (Yazıcı, 2001, s.91) öne sürmektedirler. Yazıcı, farklı yazarların geliştirdiği örgütsel öğrenme tanımlarını şu şekilde bir araya getirmektedir: 
$\checkmark$ Chris Argyris'e (1996, s.1) göre örgütsel öğrenme, hataların bulunması ve düzeltilmesi sürecidir. Argyris, bireylerin öğrenme süreçleri sayesinde örgütsel öğrenmenin gerçekleşebileceğini savunur.

$\checkmark$ McGill ve diğerleri (1992, s.6), “örgütün deney, gözlem, analizler sonucunda edindiği tecrübelerden bir bakış açısı ve anlayış elde etme kabiliyeti, hatalarını ve başarılarını değerlendirme istekliliği" şeklinde tanımlamışlardır.

$\checkmark$ Edwin Nevis ve arkadaşları (1995, s.73) ise, "örgütün tecrübelerine dayanarak performansını geliştirme kapasitesi veya süreçleri” olarak örgütsel öğrenmeyi açıklamaktadırlar.

$\checkmark$ Son olarak, Mark Dodgson ise örgütsel öğrenmeyi, "örgütün bilgiyi yarattığı, arttırdığı, organize ettiği ve içselleştirerek faaliyetlerinde ve kültüründe kullandığı ve aynı zamanda çalışanlarının yeteneklerini geliştirerek örgütsel etkinliği arttırmak için kurduğu yollar” şeklinde izah etmiştir (Yazıcı, 2001, s.92-93).

Bu tanımları dikkatli bir şekilde okuduğumuzda, satır aralarında, örgütlerde genellikle yapılan hatalar sonucu öğrenme ihtiyacı oluştuğu veya örgütlerin tecrübelerini arttırma arzusu içinde bulundukları gerçeği ortaya çıkmaktadır. Diğer bir değişle, örgütlerdeki yanlış uygulamalar ve örgüt deneyimleri sonucunda hataların minimize edilmesi ve tekrarlanmaması için örgütsel öğrenme gerçekleşmektedir. Ayrıca, yukarıdaki son tanımda özellikle "örgütsel bilgi" kavramı üzerine vurgu yapılarak, üstü kapalı bir şekilde bilgi yönetiminin gerekliliğinin ve devamının örgütsel öğrenme ile gerçekleşeceği anlatılmak istenmiştir. 
Her ne kadar örgütsel öğrenme, örgütlerin her türlü bilgi ihtiyacını karşılama amacına dönük görünse de; örgütün gereksinimlerinin örgüt çalışanlarınkilerle paralellik taşımasından ötürü, örgüt üyelerinin ihtiyacııı da karşılamaktadır. Çünkü, örgütsel öğrenme bireysel öğrenme süreci ile başlamaktadır. Bireysel öğrenme sonucu ortak bir tabanda oluşan bilgiler, örgütün yararına kullanılması açısından da önem taşımaktadır. Örgütsel öğrenmenin, bireysel öğrenme sayesinde gerçekleşmediği yönünde iddialar olsa da "örgütün bireysel öğrenme sayesinde zamana bağlı olarak oluşturduğu bir örgütsel belleğe, kültüre ve mitolojiye hakim olduğu" söylenmektedir (Huber, yıl, s.88-115). Zaten nedenle, örgütsel belleği, kültürü ve mitolojiyi de bireyler oluşturmaktadır.

\section{Bilgi Yönetimi Açısından Örgütsel Öğrenme}

Örgütsel öğrenmeyi, bilgi yönetim süreci içerisinde değerlendirirken, "örgütsel bilgi" kavramının daha ayrıntıı olarak açıklanması gereği vardır.

Chris Argyris'e göre örgütsel bilgi, örgütsel araştırmaların bir sonucudur ve örgütsel bilginin hangi koşullar altında oluştuğuna ilişkin iki farklı ve tümleyici yanıtın olduğunu söylemektedir. Bunlardan birincisi, örgütsel soruşturma sonucunda ortaya çıkan bilgi ile örgüt üyelerinin zihinlerindeki işle ilgili görüşlerinin, örgütle ilgili düşüncelerinin, yapılan düzenlemelerin ve uygulanan politikalar hakkındaki resmi ve gayri resmi yansımaların bulunduğu yönündeki bilgilerini oluşturan etmenleridir. İkincisi ise, karmaşık görevleri yerine getirmek için oluşturulan stratejilerin ortaya çıkardığı bilgi gereksinimidir. Argyris (1996, 
s.12-13), karmaşık görevler sonucu oluşan sorunların ve bunlara aranan bir dizi cevabın örgütsel bilgiyi oluşturduğunu savunmaktadır.

Örgütsel bilgi bu şekilde oluştuktan sonra, bunun örgüt yararına kullanılması aşamasına gelinmektedir. Bu aşama, doğal olarak bir yönetim sürecini gerektirmektedir. İşte örgütsel bilginin yaratılması sürecinden kullanılmasına kadar geçirdiği aşamaya örgütsel bilgi yönetimi denilmektedir. Bu da, ancak örgütsel öğrenme sayesinde devamlılık kazanmaktadır. Yani bilgi yönetiminin belkemiğini örgütsel öğrenme oluşturmaktadır. Bunun sonucunda örgütte oluşan kolektif bilgiler, bilgi yönetiminin bir parçası niteliğini taşımaktadır. İşte bu nedenlerden ötürü örgütsel öğrenme ile bilgi yönetimi birbirinden ayrılmayan ve birbirini tamamlayan bir yapı içerisindedir.

Bu birlikteliğin bir başka örneğini Garvin'in "Öğrenen bir örgüt yaratmak” adlı makalesinde görmekteyiz. Makalenin öğrenebilen örgütü, ‘örgütsel bilginin yaratılması, sağlanması ve aktarılması, yeni bilgi ve kavrayışları yansıtmak için davranışını değiştirme becerisine sahip olan örgüt” (Garvin, 1999, s.55) şeklinde ifade etmesi, bir bakıma örgütsel bilgi yönetim sürecinin kazanımlarını ortaya koymaktadır.

Örgütsel öğrenmenin bilgi yönetiminin devamlılığı için bir şart olduğunu, örgütsel öğrenmenin yapı taşlarını sıraladığımız zaman da görmekteyiz. Bu yapı taşlarının varlığı, örgütsel bilgi yönetimi için bir zorunluluk teşkil etmektedir. Örneğin; "örgütlerin sistematik problem çözme kabiliyetinin olması, yeni bilgilerin sistematik bir şekilde örgütün faaliyetlerinde kullanılması, örgütün geçmiş deneyimlerinden ders alınması, başka firmaların deneyimlerinden istifade edilmesi ve son olarak örgütün hem içsel hem de dışsal bilgi 
aktarımında bulunması (Garvin, 1999, s.56-69); aslında örgütün verimliliğini, üretkenliğini ve devamlılığını oluşturması açısından bilgi yönetimine katkı sağlamaktadır.

\section{Örgütsel Öğrenmede "İnsan"}

Bilgi yönetiminin devamlılığı açısından örgütsel öğrenmede insan boyutu en temel unsurdur. "Örgütsel sistemi bir bütün olarak daha iyi anlamaya çalışmak için örgütteki bireylere yardım eden ve örgütsel öğrenme sürecinin nasıl yaratılacağına yön veren insandır" (Ali Kırcalı, 1995, s.4). Örgütsel öğrenme sürecinin ve bilgi yönetiminin devamlılığında insan rollerinin çok iyi tasarlanması gerekir. Bu roller, kolektif bilginin dolayısıyla örgütsel bilginin oluşumunda temel alınması gereken bir politika oluşturacak nitelikte olmalıdır. Örgüt üyeleri tarafından paylaşılan bilgiler, örgütsel öğrenmeyi körükleyerek bilgi yönetimi sürecinin devamlılığını sağlamaktadır. "Çalışanların kendi sorumlulukları ile ilgili aktif bir rol üstlenmeleri, yaptıkları işler sonucunda en iyi enformasyonu edinip paylaşmaları ve temel sorunlara dönük kalıcı çözümlere şekil vermede sahici yetkilendirmeyi iyi kullanmaları gerektiği” (Argyris, 2001, s.94), bilgi yönetiminin örgütsel öğrenme sürecinde insan yaklaşımı açısından üzerinde durulması gereken en önemli konulardan birisidir. Örgütteki gerek bireysel, gerekse kurumsal düzeydeki bilgilerin paylaşılması için; bu bilgilerin örgüt-içi iletişim modellerini kullanarak üretilmesi gerekir. Ayrıca, örgütsel öğrenmenin temelinde bireysel öğrenmenin yattığı da unutmamalıdır. Özellikle, örgüt üyelerinin hafızalarındaki bilgi haritalarının örgütsel öğrenmeye dolayısıyla bilgi yönetimine doğrudan etkisi bulunmaktadır. Şöyle ki; bireyler kendilerine has değer yargılarını ortak bir zeminde diğer örgüt üyeleri ile paylaşarak ortak fikirler 
oluştururlar. İşte bu fikirlerin temelinde, bireyin tecrübe ve alışkanlıklarının yanı sıra beynindeki bilgi haritaları da yatmaktadır. Bireyin zihninde oluşan bilgi haritasının temelinde ise, onun örgüt içindeki tutum ve davranışları ile iş alışkanlıkları yatmaktadır. Bu tutum ve davranışlar da, örgüt üyesinin örgütteki çalışma biçiminden örgütün bireye ve bireyin de örgüte karşı olan tutumlarına kadar uzanan bir yelpaze gibidir. Bireyin örgütün çıkarı için ortak bir zemin oluşturulmasındaki davranış değişikliği, bireysel bilgi ve değişimin kolektif bilgi sürecine dahil olması, örgüt çalışanlarının geçmiş yaşamlarındaki toplu deneyimleri, sonuçta örgütsel öğrenme sürecinin birer parçasıdır ve her bir parçanın oluşmasında insan unsurunun katkısı, en temel faktör olarak yer almaktadır.

\section{Kesişim Kümesi Modeli}

Neo-klasik bir yönetim anlayışı olan davranışsal yaklaşımın ortaya çıkardığı “insan modeli” , aslında bilgi yönetimi alanının arzuladığı insan formasyonu ile paralellik göstermektedir. Hatta, bilgiye dayalı örgütlerin etkin ve sürekli bir yönetimi gerçekleştirebilmeleri için, öncelikle örgütsel bilgi yönetimini uygulamaya koymaları ve bunun devamlılığı için örgütsel öğrenme sürecini takip etmeleri gerekmektedir.

Yukarıdaki bu ifadelere bağlı kalınarak aşağıdaki küme modeli geliştirilmiştir. 


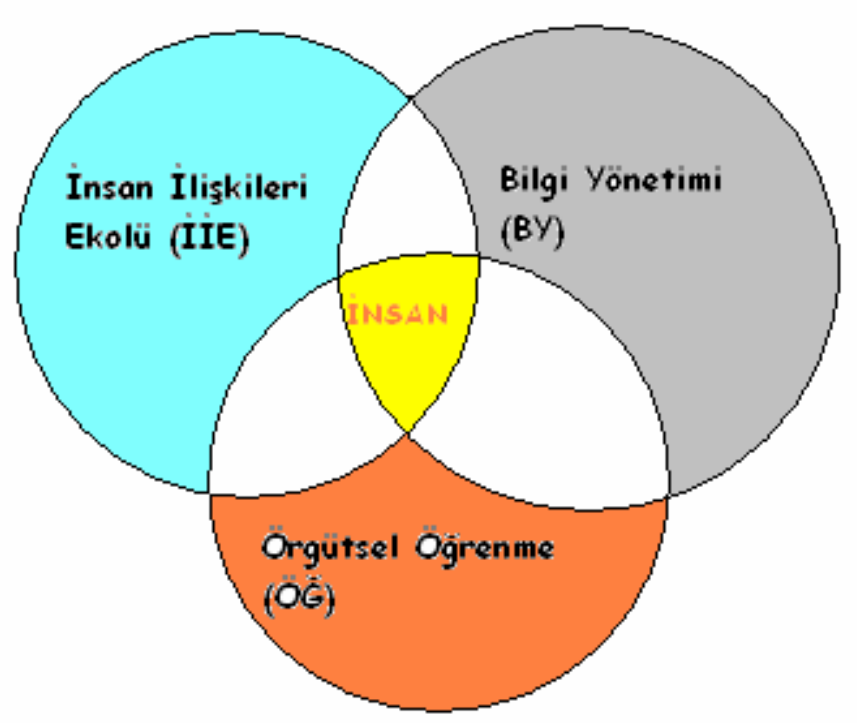

Şekil 2: Küme Modeli

Kümeye bakarak sözü edilen insan modelinin görselleştirilen üç kümenin ara kesitinden oluştuğunu belirtebiliriz. Bu modelin ortaya koymaya çalıştığı temel tez, örgütsel seçiminde insanın, insan ilişkileri ekolünün öngördüğü insan modeli sayesinde bilgi yönetimine katkıda bulunmakta oluşudur. Örgütte bilgi yönetiminin devamlılığı da, ancak örgütsel öğrenme sayesinde gerçekleşmektedir. $\mathrm{Bu}$ önermeden hareketle, her kümenin insanın davranışlarından kaynaklanarak gerçekleşen ve Şekil 3'de maddeler halinde sıralanmış aşamalarına göz atmakta yarar vardır.

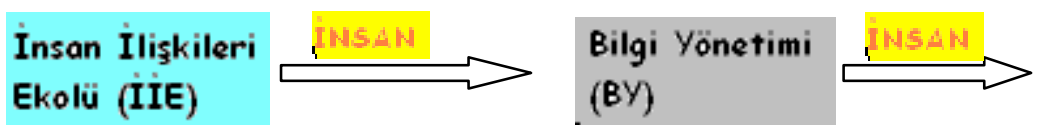

\section{Orgutsel Ogrenme (OG)}

-Sosyal bir varlık olarak insan, -Örgüt çalışanlarının iş tatmininin ve üretkenliğinin sağlanması -Örgüt üyelerinin işteki motivasyonlarının arttırılması
-Bilgiyi bireysel düzeyde yaratan insan -İnsan zihnindeki bilgi haritası

-Bilgiyi kolektif bir bilinçle aktaran insan -Bilginin insanlar arasında sosyalleşerek örgütsel seviyeye çıkarılması
-Bireysel Bilgi

-Kolektif bilgi sonucunda çalışanların oluşturduğu örgütsel bilgi

-Örgüt üyeleri aracılığı ile örgütün sistematik problem çözebilme becerisi kazanması -Örgütün çevreye uyum sağlaması için yeni yaklaşımların örgüt 
Şekil 3: Küme Modeli, Kümelerinin İşlev ve İçerikleri

\section{Sonuç ve Değerlendirme}

Bu çalışmada, makro düzeydeki örgüt teorileri içerisinde yer alan ve bir yönetim düşüncesi olan neo-klasik insan ilişkileri akımındaki insana ilişkin olarak varsayılan temel özellikler ile bilgi yönetimi alanının insana yönelik getirdiği insan modeli açıklanmaya çalışılmıştır. Aslında her iki düşünce sisteminde de devamlılığının örgütsel öğrenmeye bağlı olduğu ortaya çıkmıştır. Bu önermeye dayanarak yukarıdaki küme modeli oluşturulmuş ve örgüt verimliliğinin ve devamlılığının insana yönelik yatırımların yapılması ile gerçekleşebileceği değerlendirmesine varılmıştır. Her ne kadar insan odaklı olarak geliştirilen bu model, örgütsel seçimlerde tek seçenek olarak yer almasa da; çalışma, bir makro örgüt teorisi olan davranışsal akım ile bir mikro örgüt teorisi olan örgütsel öğrenme alanlarında ortak payda olarak insanı birleştirmesi ve bunu bilgi yönetimi alanına uyarlaması açısından önem taşımaktadır. Ayrıca, insan ilişkileri yaklaşımının katı hiyerarşiye, güçlü örgüt merkezine ve 'makine örgüte' karşı olması, örgütlerdeki bilgi yönetiminin bu yaklaşım bağlamında kolay gelişmesine olanak sağlayacaktır. İnsan doğasının özünde iyi olması, insanın 
özgür seçimlerinin bulunması gibi öngörüleri ile insanı romantik ve idealist olarak ele alan bu ekol, sonuçta insan zihnindeki bilgi haritalarının oluşmasını, örgüt içi bilginin kolektif bir şekilde yayılmasını, örgütteki örtük bilginin ortaya çıkışını ve örgütteki bilginin örgüt içi ve örgüt dışı etkileşime geçerek çevre ile uyumunu ortaya koymasını tanımlayıcı olgular olarak değerlendirip, belirtilen içerikteki bilgi yönetiminin desteklenmesi gereğini ifade etmektedir.

\section{Kaynakça}

Accel Team.Com. (2001). "Human Relations School of Management: Employee Motivation Theory and Practice". [Çevrim içi], Elektronik adres: http://www.accel-team.com/human_relations/index.html [erişim tarihi].

Kırcalı, A. (1995). Benchmarking. [Çevrim içi], Elektronik adres:

[http://www.geocities.com/akircali/yazilar/Benchmarking.htm] [erişim tarihi].

lowa State University. Tech, Knowledge and Community: Knowledge Management and the Human Factor. [Çevrim içi], Elektronik adres: [http://www.extension.iastate.edu/mt/dcoates/archives/000035.html [15 Ocak 2002

Allee, V. (1997). The Knowledge evolution: Expanding organizational intelligence. Boston: Butterworth-Heinemann.

Argyris, C. ve Schön, D.A. (1996). Organizational learning II: Theory, method and practice. Reading, Mass.: Addison-Wesley.

Argyris, C. (2001). Öğrenmenin önünü tıkayan iyi iletişim. Harvard Business Review dergisinden seçmeler: Örgütsel öğrenme içinde (s. 93-115). İstanbul: BZD Yayıncılık.

Baransel, A. (1979). Çağdaş yönetim düşüncesinin evrimi: Klasik ve neo-klasik yönetim ve örgüt teorileri - cilt 1. İstanbul: İstanbul Üniversitesi.

Barutçugil, İ. (2002). Bilgi yönetimi. İstanbul: Kariyer Yayıncılık.

Bennis, W.G. (1967). Leadership theory and administrative behavior: The problem of authority. Administrative Science Quarterly, 4(3): 263.

Daft, R.L. (2000). Management. Forth Worth: The Dryden Press. 
Davenport, T.H. ve Prusak, L. (2001). İs dünyasında bilgi yönetimi: Kuruluşlar ellerindeki bilgiyi nasıl yönetirler. İstanbul: Rota Yayın.

Davis, K. (1977). Human behavior at work: Organizational behaviour. New York: McGraw Hill Book Company.

Eren, E. 1996. Yönetim ve organizasyon. İstanbul: Beta yayınları.

Ross; F. Murdick, R. (1977). People, productivity and organizational structure. Contemporary readings in organizational behavior. F. Luthans (ed.). içinde (s.122). New York: McGraw Hill,

Garvin, D.A. (1999). Öğrenen bir örgüt yaratmak. Harvard Business Review dergisinden seçmeler: Bilgi yönetimi içinde (s.51-81). İstanbul: BZD Yayıncılık.

Hicks, H.G. (1979). Örgütlerin yönetimi: Sistemler ve beşeri kaynaklar açısından. Osman Tekok vb. (çev.) Ankara: Turhan Kitapevi.

Kalite Derneği Öğrenen Organizasyonlar Uzmanlık Grubu. (1998). Öğrenen organizasyonlar. İstanbul: Kal-Der Yayınları.

Karakaş, M. (2002). Bilgi yönetimi nedir?: Gerçek hayattan uygulamalar. [Çevrim içi], Elektronik adres: http://www.bilgiyonetimi.org/bynedir.htm

Keskin, H. ve Kalkan, V.D. (2002). İşletmelerde bilgi yönetiminin tanımlanması ve kavramsallaştırılması: KOBI'lerde bilgi yönetimi araçlarının kullanımına ilişkin bir araştırma. I. Ulusal Bilgi, Ekonomi ve Yönetim Kongresi bildirileri. [Çevrim içi], Elektronik adres: http://iibf.kou.edu.tr/ekonomi/tamprogram.htm.

Koçel, T. (2001). İşletme yöneticiliği. İstanbul: Beta.

Lim, D. ve Klobas, J. (2000). Knowledge management in small enterprises. The Electronic Library, 18(6).

Mayo, E. (1945). The social problems of an industial civilization. Boston: Harvard University Graduate School of Business Administration.

Edwin C. Nevis, Anthony J. Dibella, Janet M. Gould, "Understanding Organization As Learning System", Sloan Management Review, Vol: 36, No: 2, Winter 1995, s. 73.

Nonaka, I. (1991). The Knowlede-Creating Company. Harvard Business Review, November/December, c.69, n.6, 1991, s.1. 
Nonaka, İ. (1999). Bilgi yaratan şirket. Harward Business Review dergisinden seçmeler: Bilgi Yönetimi içinde (s.29-50). İstanbul: BZD Yayıncılık.

O'Connor, E. (1999). Minding the workers: The meaning of "human" and "human relations" in Elton Mayo. Organization, 6(2): 223-246.

Onaran, O. (1971). Örgütlerde karar verme. Ankara: Ankara Üniversitesi Siyasal Bilgiler Fakültesi Yayınları.

Öğüt, A. (2001). Bilgi çağında yönetim. Ankara: Nobel Yayıncılık.

Probst, G. ve Büchel, B.S.T. (1997). Organizational learning: The competitive advantage of the future. London: Printince Hall.

Sabuncuoğlu, Z. ve Tüz, M. (1995). Örgütsel psikoloji. Bursa: Ezgi Kitabevi.

Sağsan, M. (2002). Bilgi savaşı: Siperlerden klavyelere taşınan bir harekatın anatomisi. Avrasya Dosyası: İstihbarat Özel, 8(2): 217.

Scott, W.G. (1967). Organization theory: A behavioral analysis for management. Homewood, III: R.D. Irwin.

Scott, W.R. (2003). Organization: Rational, natural and open systems. New Jersey: Pretice Hall.

Svetvilas, C. (2001). The Human factor: Intellectual capital guru Nick Bontis Discusses KM's missing links. Intelligent Enterprice, 4:11, 15243621, $7 / 23 / 2001$.

Vail, E.F. (1999). Knowledge mapping: getting started with knowledge management. Information Systems Management, 16 (4): 16:23.

Walz, E. (1998). Information warfare: Principles and operations. Boston: Artech House.

Wren, D.A. (1972). The Evolution of management thought. New York: The Ronald Press.

Yazıcı, S. (2001). Öğrenen organizasyonlar. İstanbul: Alfa. 